\title{
Article \\ Seismic Response of Container Crane under Near-Field and Far-Field Ground Motions
}

\author{
Van Bac Nguyen ${ }^{1} \mathbb{D}$, Jungwon Huh ${ }^{1, * \mathbb{D}}$, Bismark Kofi Meisuh ${ }^{1}$, Jongwoo Kim ${ }^{1}$ and Inn-Joon Park $^{2} \mathbb{D}$ \\ 1 Department of Architecture and Civil Engineering, Chonnam National University, Gwangju 61186, Korea; \\ 186197@jnu.ac.kr (V.B.N.); 187129@jnu.ac.kr (B.K.M.); civil5498@ygpa.or.kr (J.K.) \\ 2 Department of Civil Engineering, Hanseo University, Seosan 31962, Korea; geotech@hanseo.ac.kr \\ * Correspondence: jwonhuh@chonnam.ac.kr; Tel.: +82-62-530-1655
}

check for updates

Citation: Nguyen, V.B.; Huh, J.;

Meisuh, B.K.; Kim, J.; Park, I.-J.

Seismic Response of Container Crane under Near-Field and Far-Field Ground Motions. Appl. Sci. 2021, 11, 1740. https://doi.org/10.3390/ app11041740

\section{Academic Editor:}

Amadeo Benavent-Climent

Received: 28 January 2021

Accepted: 12 February 2021

Published: 16 February 2021

Publisher's Note: MDPI stays neutral with regard to jurisdictional claims in published maps and institutional affiliations.

Copyright: (c) 2021 by the authors. Licensee MDPI, Basel, Switzerland. This article is an open access article distributed under the terms and conditions of the Creative Commons Attribution (CC BY) license (https:// creativecommons.org/licenses/by/ $4.0 /)$.
Featured Application: This study considers the seismic response of a container crane subjected to near-field and far-field ground motions by a shaking table test on a 1/20 scale crane model. The results are presented focusing on the comparison of the seismic response of the container crane in terms of the maximum internal forces in the landside and seaside legs, the maximum portal drift, and acceleration when subjected to near-field and far-field ground motions.

\begin{abstract}
In this study, the seismic response of a container crane under near-field and far-field ground motions was investigated using a shaking table test on a $1 / 20$ scale crane. The $1 / 20$ scale crane was designed and fabricated based on the similitude laws, in which three independent quantities: geometric length, acceleration, and elastic modulus, were used to design the $1 / 20$ scale crane. A series of shaking table tests were conducted at the Seismic Research and Test Center, Pusan National University, Yangsan Campus to evaluate the seismic response of the scale crane under near-field and far-field ground motions. The results show that the near-field ground motions can cause larger internal forces (that is, axial force and two bending moments) in the landside and seaside legs and larger portal drift than the far-field ground motions. The portal drift of the container crane subjected to the near-field ground motions was $43 \%$ higher than that of the container crane subjected to the far-field ground motions. Furthermore, when subjected to the near-field ground motion, the bending moment in the crane's portal leg was 37\% higher than the bending moment when the crane was subjected to the far-field ground motions.
\end{abstract}

Keywords: shaking table test; response spectrum; acceleration time history; similitude law; strain gauges; portal drift; near-field and far-field ground motions

\section{Introduction}

Container cranes are special equipment widely used at seaports to transfer containers between ships and harbors. Since they are located at the seaport where strong typhoons and earthquakes are frequent occurrences, they have received more attention recently due to the effect their damage or collapse would have on the economy. For example, after the Kobe earthquake in 1995, Chang [1] showed that physical damage to the container crane occurred within a timeframe of seconds or minutes, but the ensuing economic impacts were prolonged by months or years. Despite having an important role in freight, the container crane has been one of the most vulnerable pieces of equipment at harbors, as observed in past earthquakes. It is, therefore, necessary to study the seismic response of a container crane under earthquakes to reduce seismic damage on existing and new container cranes. 
In past studies conducted by various researchers, the two methods used to evaluate the seismic response of a container crane are the finite element method on a prototype container crane and the shaking table test of a scale container crane. In the finite element method [2-6], real earthquakes or artificial earthquakes were used to analyze container crane by time history analysis. Tran et al. [3] used 20 real earthquakes to evaluate the sensitivity of parameters for the ship-to-shore container crane. In their study, the 20 earthquakes were adjusted based on their response spectra by scaling the spectra value at the container crane's fundamental period to match the spectra value of an elastic response spectrum at that period. Tran et al. [7] conducted a fragility analysis on a container crane using 10 real earthquakes and 10 artificial earthquakes, in which the response spectra of 10 real earthquakes were matched to an elastic response spectrum, while 10 artificial earthquakes were created from the elastic response spectrum. Then, the intensity of 20 earthquakes (10 adjusted real earthquakes and 10 artificial earthquakes) was increased according to the spectra value at the container crane's fundamental period. For the shaking table test, various authors evaluated the seismic response of a container crane by using $1 / 50,1 / 25,1 / 20$, $1 / 15,1 / 10$, and $1 / 8$ scale crane models [8-13]. Kosbab et al. [14] only used two earthquakes to evaluate a container crane's seismic response, including an uplift phenomenon. The two earthquakes were matched to the design spectra for the port of Los Angeles and Long Beach. Jin and Zhang [10] used four earthquakes, which comprised three real earthquakes and one artificial earthquake, to compare a container crane's seismic response with and without the base isolator by utilizing a shaking table test. Due to time and economic limitations, a shaking table test usually uses fewer input ground motions. The selection of earthquake records used for the shaking table test is an issue of concern, affecting the seismic response of a container crane. Besides, there is a need to discuss the scale of a prototype container crane for the shaking table test to accurately reflect its seismic response.

To accurately reflect the seismic response of the prototype crane, a 1/20 scale crane was designed according to the similitude law $[15,16]$. The similitude law allows for conversion of the prototype crane into a lab-sized scale crane, keeping homologous dynamic properties between the prototype and scale container crane. A number of researchers have investigated the seismic response of a container crane by employing the shaking table test on a scale crane model. For example, $1 / 20$ and $1 / 10$ scale container cranes were built to study the seismic response of the container crane, including uplift and derailment [17]; a 1/50 scale container crane was examined to evaluate the effect of a base isolator on the strain and acceleration amplitude under earthquakes' load [10]. Azeloglu [12] used shaking table test results on a $1 / 20$ scale container crane to build a mathematical model for the crane. Jin [8] used the similitude law to make a 1/50 scale container crane and studied its seismic response under vertical component earthquakes using a shaking table test. The shaking table test results on the $1 / 50$ scale crane agreed quite well with those of the prototype crane obtained from the finite element method. In this study, a 1/20 scale container crane was built from a prototype container crane at Gwangyang port using the similitude law. A series of shaking table tests were conducted at the Seismic Research and Test Center, Pusan National University, Yangsan Campus.

Past research work on structures, such as a cable-stayed bridge [18], low-rise shear walls [19], embankment dams [20], and concrete gravity dams [21], showed that near-field ground motions have a more significant effect on the seismic response of the respective structures than far-field ground motions. Grimaz and Malisan [22] showed that near-field and far-field ground motion are different in intensity, nature, and typology and suggested different scale factors for near-field and far-field ground motions. Pnevmatikos et al. [23,24] studied the seismic responses of offshore platforms subjected to near-field ground motions with distinct pulses, and taking into account the pile-soil-structure interaction effects. The offshore platforms, which were steel structures and located in a sea region, were similar to container crane structures. The study showed that the near-field ground motions caused more intensive structural response than the far-field ground motions. Peng et al. [25] developed fragility curves based on a local displacement ratio and deflection ratio for 
gantry cranes subjected to near-field ground motions. They evaluated the probability of uplift for the crane according to the earthquake's peak ground acceleration. In this study, one near-field, Gazli USSR Iran, and two far-field ground motions, Nahanni Canada, and Mineral Viginia earthquakes, were matched to a Korean elastic design response spectrum. Then, the acceleration time history of the adjusted ground motions was applied in the trolley-boom direction to investigate the seismic response of the scale container crane in terms of the internal forces in the landside and seaside legs, drift of the portal frame, and acceleration.

\section{Shaking Table Test of Container Crane}

This section presents details of the prototype container crane, designing the $1 / 20$ scale crane, and the instrumentation setup to obtain the data from the shaking table tests for evaluating the crane's seismic response.

\subsection{Shaking Table}

The shaking table test was carried out at the Seismic Research and Test Center, Pusan National University, Yangsan Campus. The shaking table used for this test can be excited in three directions and has a plan dimension of $2.5 \mathrm{~m} \times 2.5 \mathrm{~m}$. The shaking table can transfer a maximum acceleration of up to $10 \mathrm{~g}$ and frequencies from 0.1 to $60 \mathrm{~Hz}$.

\subsection{A $1 / 20$ Scale Container Crane}

A container crane located at Gwangyang port was employed to design a 1/20 scale container crane. The scale factor of $1 / 20$ was selected based on the size of the shake table in the Seismic Research and Test Center. The basic properties of the prototype crane include a total height of $78 \mathrm{~m}$ from the ground to the top of the crane, a trolley boom girder length of $136 \mathrm{~m}$, a portal beam height of $17.5 \mathrm{~m}$, a crane rail span of $30.5 \mathrm{~m}$, and a total mass of approximately 1175 tons. The total mass of the prototype crane comprises the self-mass of the crane of 885 tons and the mass of other non-structural components of 290 tons. The other non-structural components include the machinery house, drive trucks, stairs, stowed pins, snag device, and boom hoist rope. The scale factors (see Table 1) were calculated based on the similitude law to design the $1 / 20$ scale crane. Three independent quantities: geometric length, acceleration, and elastic modulus, were used as a basis to establish the other factors. During seismic excitations, the legs of the container crane will experience large strains due to their bending deformation caused by the inertia loads of the crane's frames and other components. Therefore, the container crane's legs are the most critical and vulnerable components of the crane structure, and their stiffness should be given priority to satisfy when designing the $1 / 20$ scale crane. In this study, each part of the $1 / 20$ scale crane's cross-sections could not be designed according to the scale factor for the geometric length due to the limitation of size. Therefore, they were designed using the scale factor for the moment of inertia to meet the equivalent stiffness of the $1 / 20$ scale crane. The scale factors for converting the quantities from the prototype crane to the scale crane were determined by Equation (1):

$$
S_{l}=\frac{L}{l} ; S_{E}=\frac{E}{e} ; S_{a}=\frac{A}{a} ; S_{m}=\frac{M}{m} ; S_{t}=\frac{T}{t} ; S_{I}=\frac{I}{i}
$$

where $S_{l}, S_{E}, S_{a}, S_{m}, S_{t}$, and $S_{I}$ are the scale factors of geometric dimension, elastic, acceleration, mass, time, and moment of inertia, respectively. It should be noted that the uppercases in Equation (1) describe the quantities of the prototype crane, while lowercases indicate the quantities of the scale crane. 
Table 1. Scale factors for designing the $1 / 20$ scale crane.

\begin{tabular}{cccccc}
\hline Quantities & Symbol & Scale Factor & Quantities & Symbol & Scale Factor \\
\hline Geometric length, $l$ & $S_{l}$ & 20 & Mass, $m$ & $S_{m}=S_{E} \cdot S_{l}^{2}$ & 400 \\
Elastic modulus, $E$ & $S_{E}$ & 1 & Time, $t$ & $S_{t}=S_{E} \cdot S_{l}^{1 / 2}$ & 4.472 \\
Acceleration, $a$ & $S_{a}$ & 1 & Moment of inertia, $I$ & $S_{I}=S_{l}^{4}$ & 160,000 \\
\hline
\end{tabular}

The $1 / 20$ scale crane is shown in Figure 1. The total converted mass of the scale crane was $2939 \mathrm{~kg}$. After downscaling the prototype crane's cross-section, the self-frame mass of the scale crane was only $235.5 \mathrm{~kg}$, thus requiring the introduction of additional mass to the scale crane [26]. Consequently, an additional mass of $2703.5 \mathrm{~kg}$ was attached to the scale crane in two ways: by using steels bars, which were attached to the trolley-boom girders and apex beam by weldings and bolts; and lead ingots, which were attached to the upper landside and seaside legs, the lower landside and seaside legs, portal beams, and sill beams by using steel ties to avoid influencing their stiffness. The boundary condition for the scale container crane was modeled as pin support, which allowed the crane leg to rotate about the y-axis (perpendicular to the trolley-boom direction) but restrained movement in both the horizontal and vertical directions.

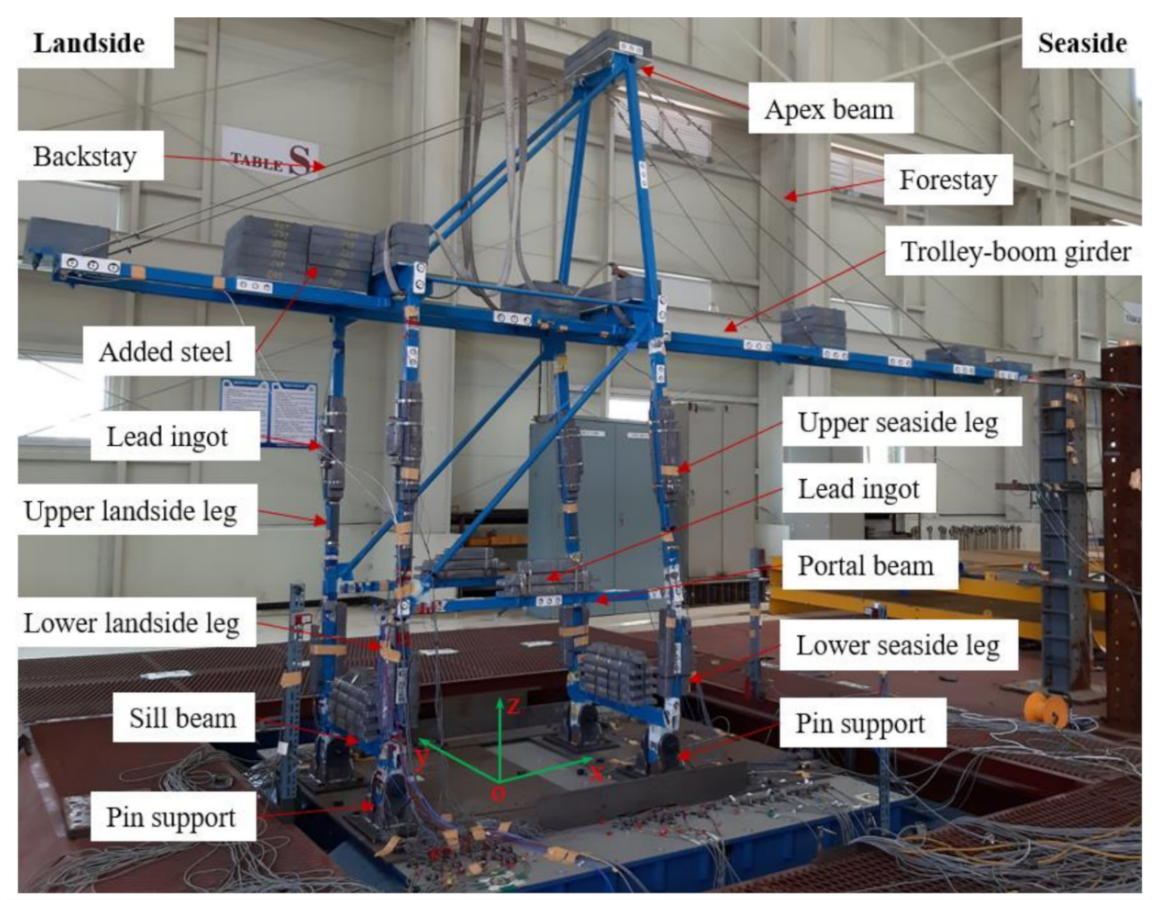

Figure 1. The $1 / 20$ scale container crane.

\subsection{Instrumentation}

Three demand parameters: strength, displacement, and acceleration, were evaluated in this study. Thirty-two strain gauges were installed on the scale crane's landside and seaside legs to determine the strength demand on the scale crane. The instrumentation plan is shown in Figure 2. The symbol " $\mathrm{S}$ " indicates the location of strain gauges, " $\mathrm{D}$ " shows the locations that were monitored by a camera to estimate the displacement of the scale crane, and " $\mathrm{A}$ " indicates the locations of accelerometers to determine acceleration. Internal forces due to seismic excitation were determined via strain gauges attached to the columns' top and bottom ends. The internal forces in the landside legs were determined at four locations labeled S1 to S4, and that in the seaside legs were determined at four locations labeled S5 to S8. The strain gauges were attached to four sides of the column at each location, so two moments and an axial force could be determined from three strain gauges. However, if no strain gauges on each section were broken, the average of the estimated internal forces was 
used. The strain gauges used in this testing were type FLA-5-11 of Tokyo Sokki Kenkyujo with a gauge length of $5 \mathrm{~mm}$, gauge resistance of $120 \pm 0.5 \Omega$, and coefficient of thermal expansion of $11 \times 10^{-6} /{ }^{\circ} \mathrm{C}$. The drift of the portal frame, an essential seismic response of a container crane, was determined at two locations, D1 and D2, using a camera. The NIKON D5500 camera with a 50-mm lens was used in this instance. The camera was focused on D1 and D2, where target patterns were attached to the scale container crane (see Figure 2). Three points for recording acceleration were A1, A2, and A3. A1 was the location on the trolley-boom girder, and nearest the gravity center of the scale container crane, A2 was the location at the intersection of the portal beam and the seaside column leg, and A3 was the location at the intersection of the portal beam and the landside column leg. The acceleration of three points was recorded by using the triaxial accelerometer Kistler.

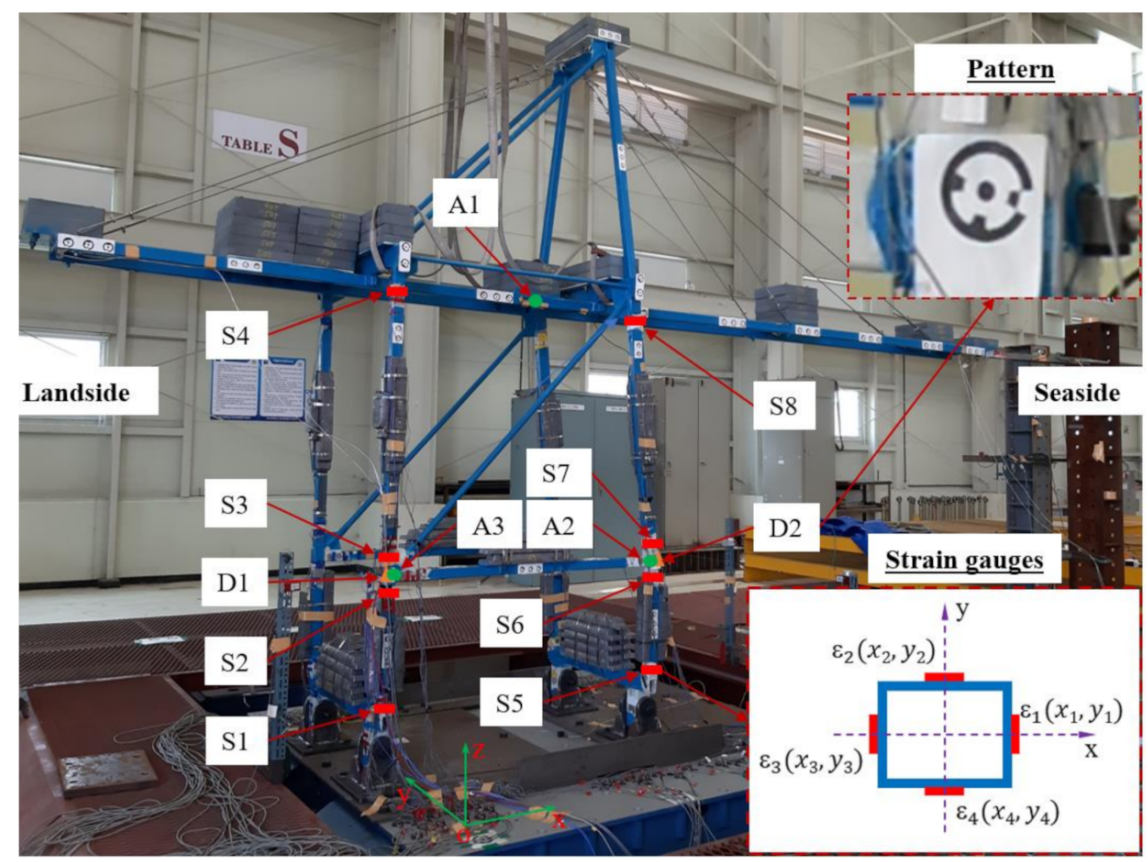

Figure 2. Locations of the strain gauges, displacement, and accelerometer.

\section{Input Ground Motions}

This section discusses the characteristics of original input ground motions, matching original input ground motions to the target response spectrum, alongside the process of scaling down the matched input ground motion to make input data for the shaking table test.

\subsection{Original Input Ground Motion}

To evaluate the effects of the near-field and the far-field ground motions on the container crane's seismic response, a near-field and two far-field ground motions were used to make input ground motions for the shaking table test in this study. The near-field ground motions are generally defined to be limited to areas within an epicentral distance (EpiD) of approximately $20 \mathrm{~km}$ from an epicenter [20,21,27]. However, the definition of near-field ground motions is not universal because the effect of near-field ground motions on structures attenuates as the epicentral distance increases, so other factors, such as magnitude and local site conditions, have a more significant effect on structures. Furthermore, ground motions at a particular site are significantly influenced by the rupture mechanism, slip direction relative to the site, and the site's movement due to tectonic movement. For structural engineers, these characteristics are difficult to recognize when utilizing a real earthquake recorded to analyze structures' seismic response. Therefore, some main characteristics of the recorded earthquake, such as peak ground acceleration (PGA), peak ground velocity (PGV), and peak ground displacement (PGD), are used to 
consider the effect of near-field and far-field ground motions. Some characteristics of three original input ground motions, one near-field (Gazli USSR Iran earthquake) and two far-field ground motions (Nahanni Canada and Mineral Virginia earthquakes), used in this study are presented in Table 2. The comparison of peak values of ground acceleration, velocity, and displacement for two far-field ground motions and one near-field ground motion are shown in Figure 3a. For the near-field Gazli USSR Iran earthquake, PGA was $0.61(\mathrm{~g})$, PGV was $65.38(\mathrm{~cm} / \mathrm{s})$, and PGD was $25.38(\mathrm{~cm})$. The PGA of the far-field Mineral Virginia earthquake was $80 \%$ lower than the value of the near-field Gazli USSR Iran earthquake, while the PGA of the far-field Nahanni Canada earthquake was 77\% lower than the value of the near-field Gazli USSR Iran earthquake. The PGV of far-field Mineral Virginia and Nahanni Canada earthquakes was $97 \%$ and 95\%, respectively, lower than the value of the near-field Gazli USSR Iran earthquake. Both the PGD of the Mineral Virginia and Nahanni Canada earthquakes were 96\% lower than the PGD of Gazli USSR Iran earthquake. Chopra [28] showed that the response spectrum is divided into three-period ranges: acceleration-sensitive region, velocity-sensitive region, and displacement-sensitive region. These regions depend on the values of PGA, PGV, and PGD. The widths of the various regions also depend on the ratio between PGA, PGV, and PGD: the accelerationsensitive region is wider when the PGV/PGA ratio is higher; the displacement-sensitive region is wider when the PGD/PGV ratio is lower [29]. Regarding the earthquakes used in this study, the near-field Gazli USSR Iran earthquake had the widest acceleration-sensitive region, while the far-field Nahanni Canada had the widest displacement-sensitive region.

Table 2. Original input ground motions.

\begin{tabular}{|c|c|c|c|c|c|c|c|c|}
\hline Earthquake & Year & Magnitude & $\begin{array}{l}\text { EpiD } \\
(\mathbf{k m})\end{array}$ & $\begin{array}{c}\text { PGA } \\
(\mathrm{g})\end{array}$ & $\begin{array}{l}\text { PGV } \\
(\mathrm{cm} / \mathrm{s})\end{array}$ & $\begin{array}{l}\text { PGD } \\
(\mathrm{cm})\end{array}$ & $\begin{array}{c}\text { PGV/PGA } \\
\text { (s) }\end{array}$ & $\begin{array}{c}\text { PGD/PGV } \\
\text { (s) }\end{array}$ \\
\hline Nahanni Canada & 1985 & 6.76 & 22.36 & 0.14 & 3.34 & 0.98 & 0.025 & 0.296 \\
\hline Mineral Virginia & 2011 & 5.8 & 53.8 & 0.12 & 1.67 & 0.73 & 0.014 & 0.438 \\
\hline Gazli USSR Iran & 1976 & 6.8 & 12.82 & 0.61 & 65.38 & 25.38 & 0.110 & 0.388 \\
\hline
\end{tabular}

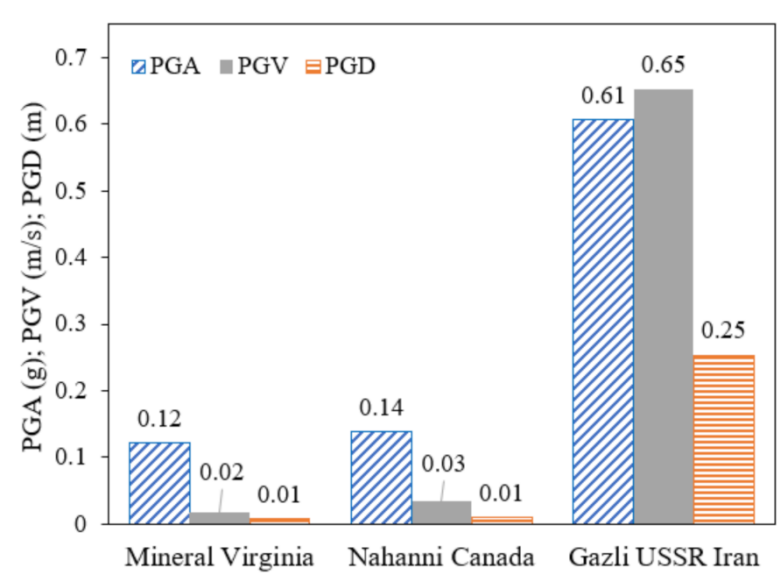

(a)

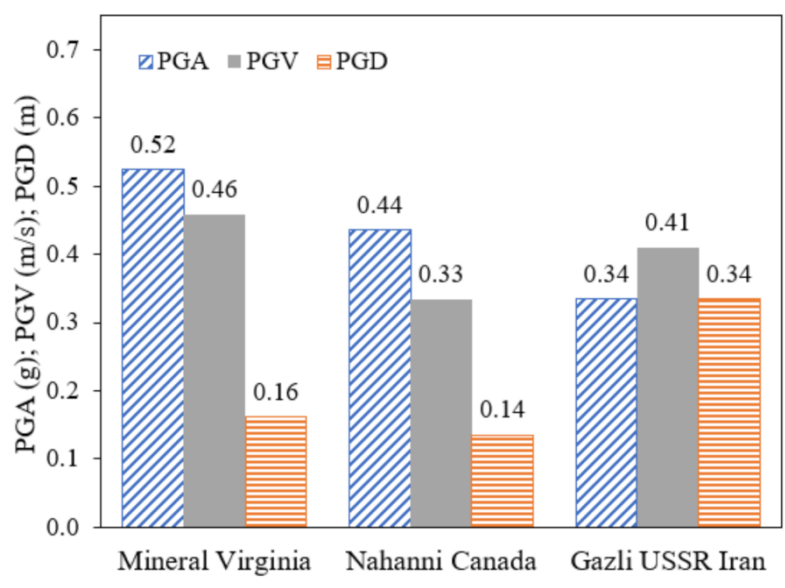

(b)

Figure 3. Peak values of ground acceleration, velocity, and displacement for three earthquakes: (a) Original earthquakes; (b) Matched earthquakes.

\subsection{Matched Input Ground Motion}

To characterize the selected ground motions according to the local condition of the prototype container crane and to normalize the effects of the intensity of the real earthquakes on the seismic response of the container crane when comparing the near-field and far-field ground motions, the three ground motions were matched to a Korean elastic response spectrum developed for the site based on the Korean Design Standard KDS 171000 [30] by 
using SeismoMatch software [31-33]. The elastic response spectrum Z1S4_2400 was developed with the following parameters: seismic zone 1, soil type S4 (deep and hard ground), and a return period of 2400 years. The comparison of the peak values of ground acceleration, velocity, and displacement of matched ground motions are shown in Figure 3b. For the matched near-field Gazli USSR Iran, PGA was $0.335(\mathrm{~g})$, PGV was $0.410(\mathrm{~m} / \mathrm{s})$, and PGD was $0.335(\mathrm{~m})$. The PGA of the matched Mineral Virginia and Nahanni Canada earthquakes was 53\% and 29\% higher than that of the matched Gazli USSR Iran earthquake, respectively, but the PGD of the matched Mineral Virginia and Nahanni Canada earthquakes was 53\% and 59\% lower than the PGA of the matched Gazli USSR Iran earthquake. The PGV of the matched Mineral Virginia earthquake was $12 \%$ higher than the value of the matched Gazli USSR Iran earthquake, while the PGV of the matched Nahanni Canada earthquake was 20\% lower than the PGV of the matched Gazli USSR Iran earthquake. The PGV/PGA and PGD/PGV ratio of the matched Gazli USSR Iran earthquake was 0.12 (s) and 0.82 (s), respectively. Therefore, the matched Gazli USSR Iran earthquake had both the widest acceleration and displacement-sensitive regions. Figure 4 shows the original and matched response spectra of near-field and far-field earthquakes, alongside the target response spectrum (Z1S4_2400).

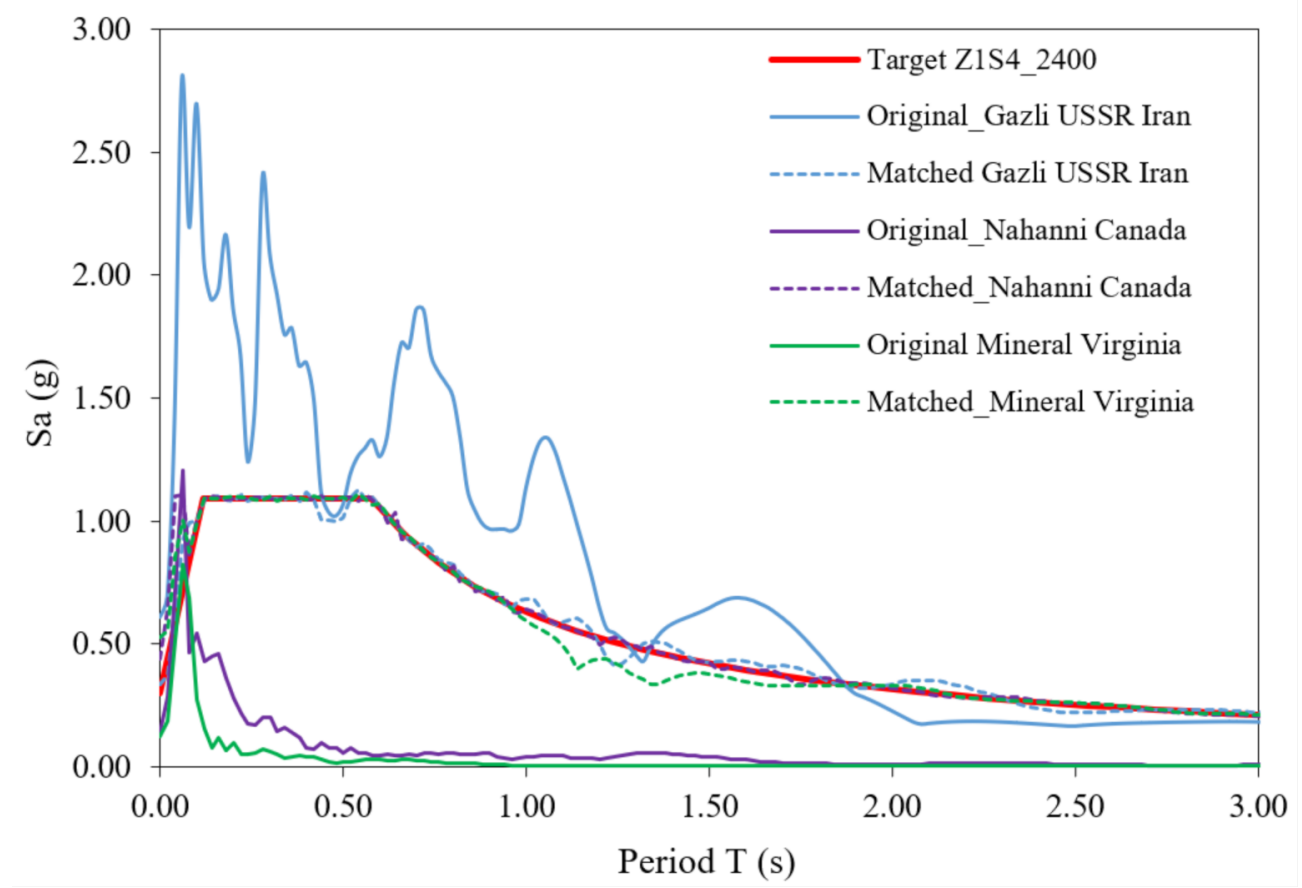

Figure 4. Original and matched response spectra.

\subsection{Scaling Matched Input Ground Motion for the Shaking Table Test}

The matched acceleration time histories were scaled down by the scale factor for time $\left(S_{t}=4.472\right)$ and acceleration $\left(S_{a}=1\right)$ to create the input ground motions for the shaking table tests. Figure 5 shows the original and matched acceleration time histories of the three ground motions and the downscaled acceleration time histories used for the shaking table tests. In this study, the ground motions were applied to the scale crane in the trolley-boom direction to cause the maximum seismic responses in the scale container crane. 


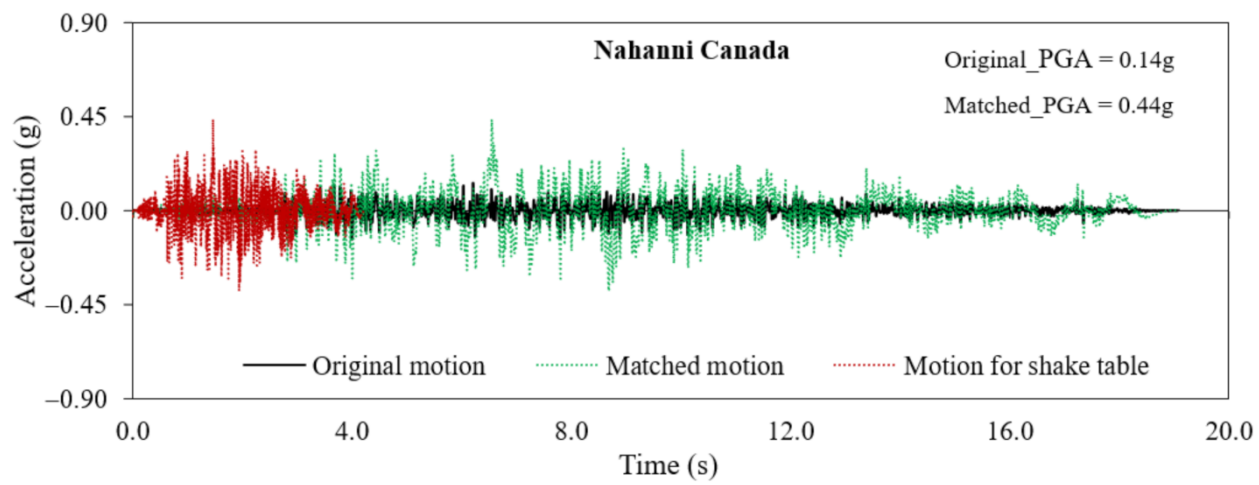

(a)

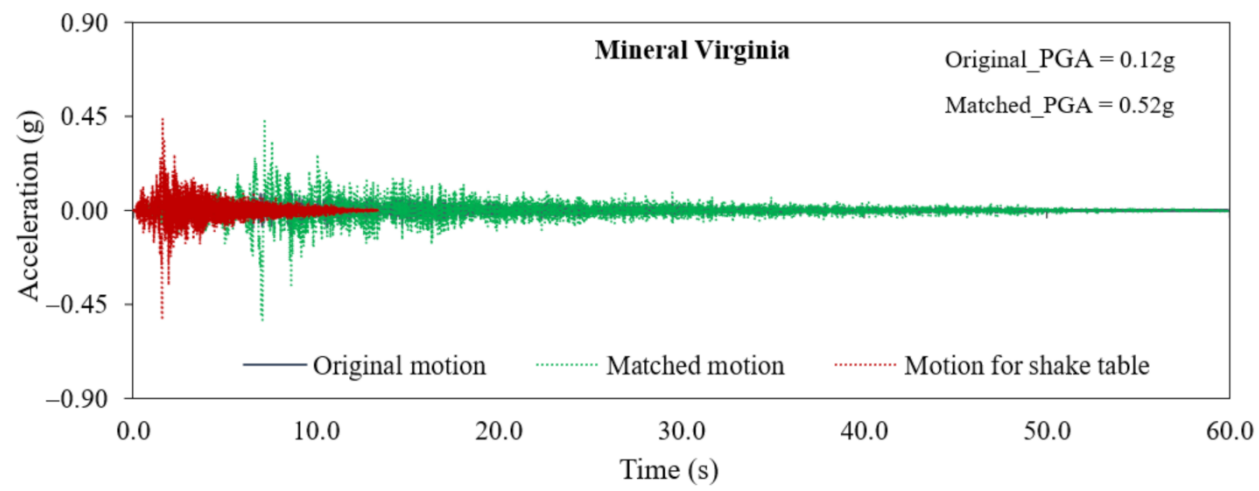

(b)

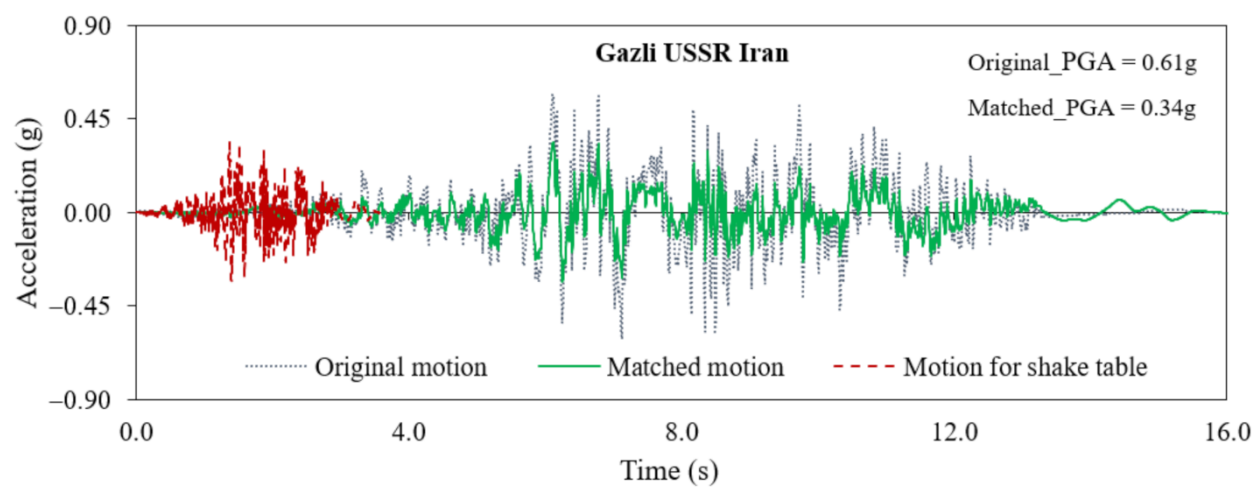

(c)

Figure 5. Acceleration time history: (a) Nahanni Canada earthquake; (b) Mineral Virginia earthquake; (c) Gazli USSR Iran earthquake.

\section{Results and Discussions}

This section discusses the seismic response of the scale container crane under the ground motions matched to the elastic design response spectrum Z1S4_2400. Details on the internal forces in the landside and seaside legs, the drift of the portal frame, alongside the acceleration response are presented herein. 


\subsection{Moment at Landside and Seaside Legs}

The bending moments $M_{y}$ about the y-axis (perpendicular to the trolley-boom direction) and $M_{x}$ about the $x$-axis (along the trolley-boom direction) were determined via four strain gauges affixed on all four sides at each section by using Equation (2). Two bending moments and an axial force were determined using three out of the four strain gauge measurements by employing Equation (2). However, if none of the four strain gauges at each section got broken during the testing, four sets of internal forces were determined from the three possible strain gauge combination (that is $\varepsilon_{1}, \varepsilon_{2}, \varepsilon_{3} ; \varepsilon_{2}, \varepsilon_{3}, \varepsilon_{4} ; \varepsilon_{1}, \varepsilon_{2}, \varepsilon_{4}$, and $\varepsilon_{1}, \varepsilon_{3}, \varepsilon_{4}$ ). The final internal forces were then determined as the average of the four. The strain gauges locations are shown in Figure 2.

$$
\left\{\begin{array}{l}
\varepsilon_{1} \cdot E=\frac{N}{A}+\frac{M_{x}}{J_{x}} \cdot y_{1}+\frac{M_{y}}{J_{y}} \cdot x_{1} \\
\varepsilon_{2} \cdot E=\frac{N}{A}+\frac{M_{x}}{J_{x}} \cdot y_{2}+\frac{M_{y}}{J_{y}} \cdot x_{2} \\
\varepsilon_{3} \cdot E=\frac{N}{A}+\frac{M_{x}}{J_{x}} \cdot y_{3}+\frac{M_{y}}{J_{y}} \cdot x_{3}
\end{array}\right.
$$

where $\varepsilon$ is the strain measured from strain gauge; $E$ is the elastic modulus of steel $\left(200,000 \mathrm{~N} / \mathrm{mm}^{2}\right) ; x, y$ is the coordinate of the strain gauge (see Figure 2); $A, J_{x}, J_{y}$ are the area, moment of inertia about the $\mathrm{x}$ - and $\mathrm{y}$-axis of the cross-section, respectively; and $N$, $M_{x}, M_{y}$ are the axial force, and the bending moment about the $\mathrm{x}$ - and $\mathrm{y}$-axis.

The maximum bending moments and axial force in the landside leg are shown in Figure 6, while the internal forces in the seaside leg are shown in Figure 7. Overall, the analyses show that the internal force of the near-field earthquake (Gazli USSR Iran earthquake) was higher than that of the far-field earthquakes (Nahanni Canada and Mineral Virginia earthquakes) for all of the observed locations. For example, the axial forces in the landside leg (location S2) and seaside leg (location S6) for the near-field earthquake were approximately 6 and $7 \mathrm{kN}$, respectively, higher than the axial force of the landside and seaside legs for the far-field earthquakes. The axial forces in the landside (location S2) for the far-field earthquakes were approximately $4 \mathrm{kN}$ for the Nahanni Canada earthquake and $6 \mathrm{kN}$ for the Mineral Virginia earthquake (refer to Figure 6a). The axial forces in the seaside leg (location S6) were approximately $5 \mathrm{kN}$ for both the Nahanni Canada and Mineral Virginia earthquakes (refer to Figure 7a). The bending moment $M_{x}$ about the x-axis in the landside leg (location S2) under the near-field earthquake was $18 \mathrm{kN} . \mathrm{cm}$. It was higher than the bending moment under the far-field earthquakes, approximately $16 \mathrm{kN} . \mathrm{cm}$ under the Nahanni Canada earthquake and $14 \mathrm{kN} . \mathrm{cm}$ under the Mineral Virginia earthquake. In the seaside leg under the near-field earthquake, the bending moment was $26 \mathrm{kN} . \mathrm{cm}$, which was higher than the bending moment of 18 and $22 \mathrm{kN} . \mathrm{cm}$ under the Nahanni Canada and Mineral Virginia earthquakes, respectively. A similar trend was observed for the maximum bending moment about the y-axis. Specifically, the bending moment in the landside leg (location S2) under the near-field Gazli USSR Iran earthquake $(127 \mathrm{kN} . \mathrm{cm})$ was $20 \%$ and $10 \%$ higher than that of the far-field Nahanni Canada $(102 \mathrm{kN} . \mathrm{cm})$ and Mineral Virginia (114 kN.cm) earthquakes. Similarly, the bending moment in the seaside leg (location S6) under the near-field Gazli USSR Iran earthquake $(123 \mathrm{kN} . \mathrm{cm})$ was $27 \%$ higher than that of both the Nahanni Canada $(90 \mathrm{kN} . \mathrm{cm})$ and Mineral Virginia $(90 \mathrm{kN} . \mathrm{cm})$ earthquakes. It is noted that even though the PGA of near-field ground motion was smaller than that of the far-field ground motions, the responses when the container crane was subjected to the near-field ground motion were higher than that of the far-field ground motions. 


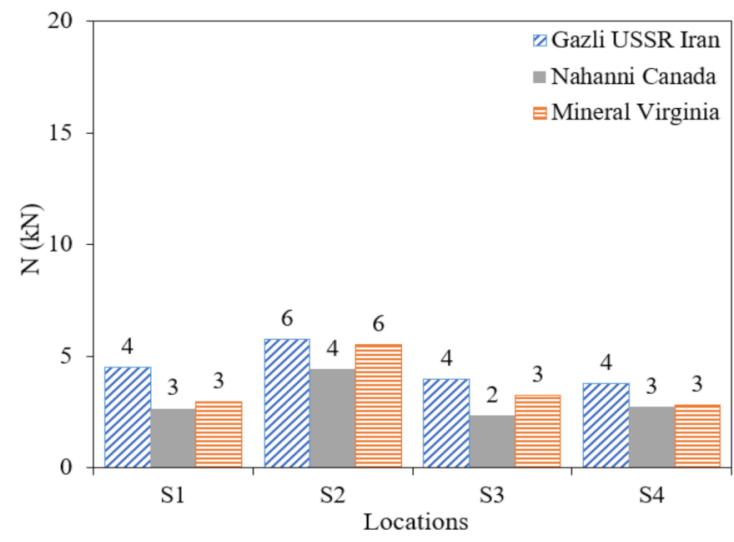

(a)

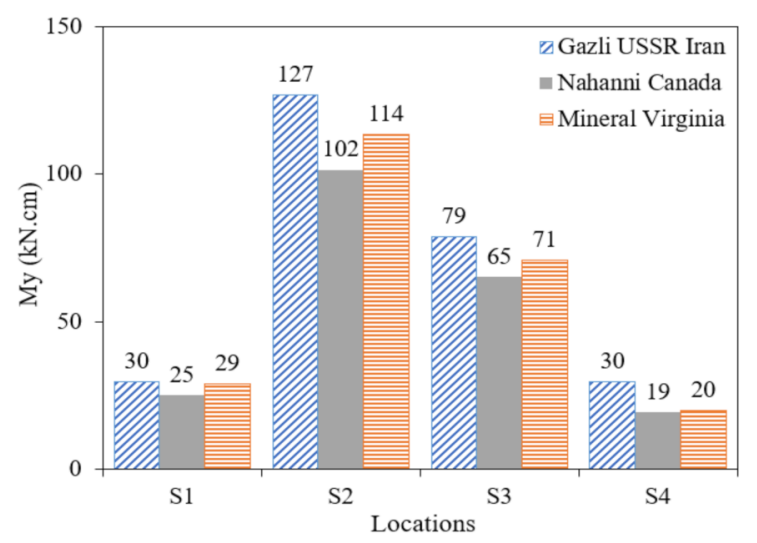

(c)

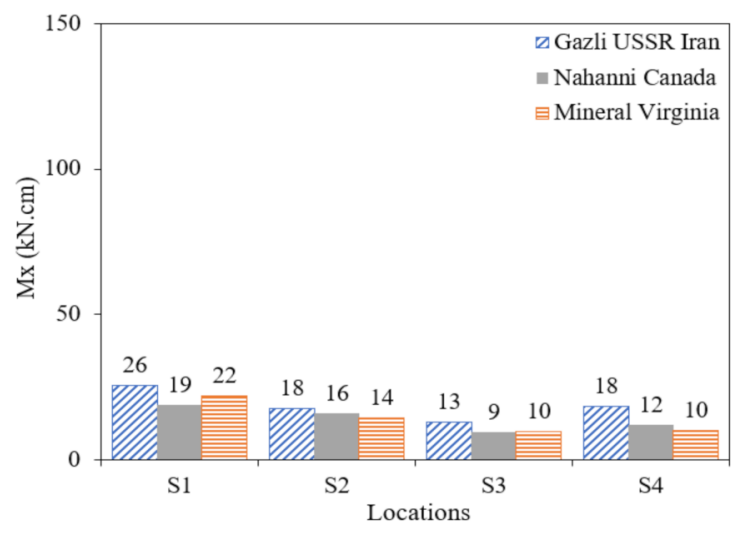

(b)

Figure 6. The maximum internal force in the landside leg: (a) Axial force; (b) Moment about the x-axis; (c) Moment about the y-axis.

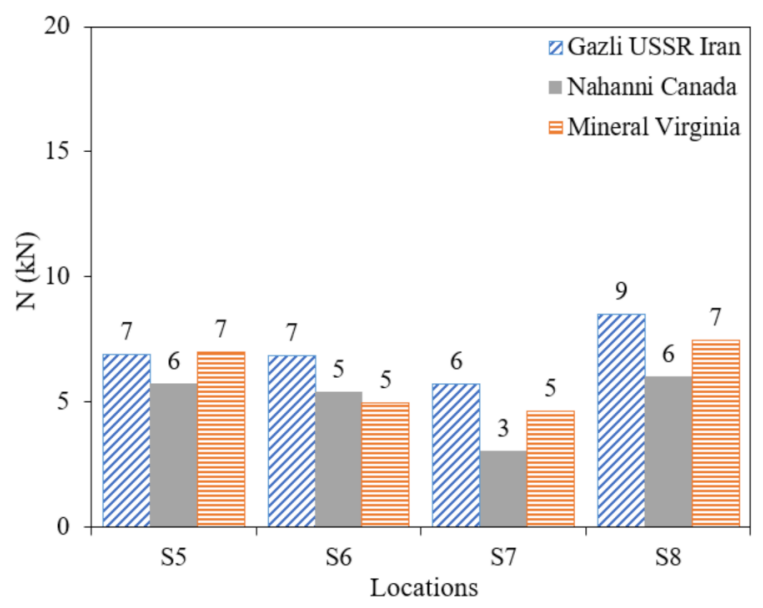

(a)

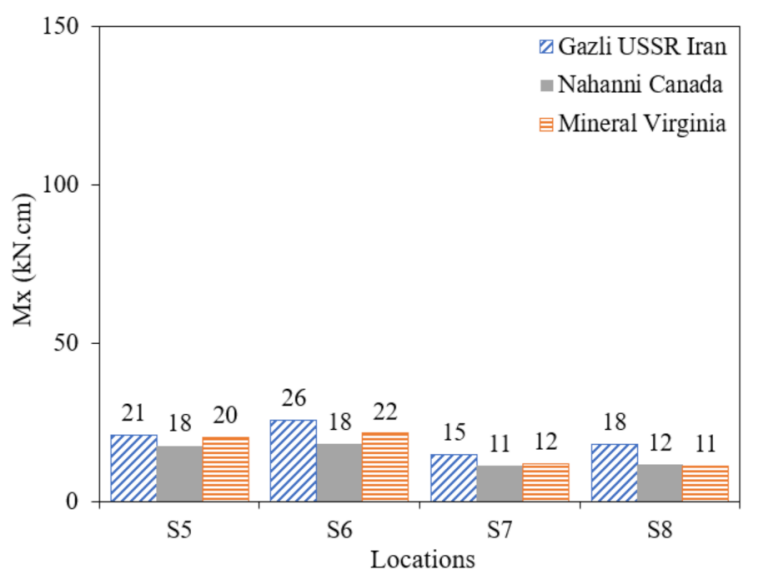

(b)

Figure 7. Cont. 


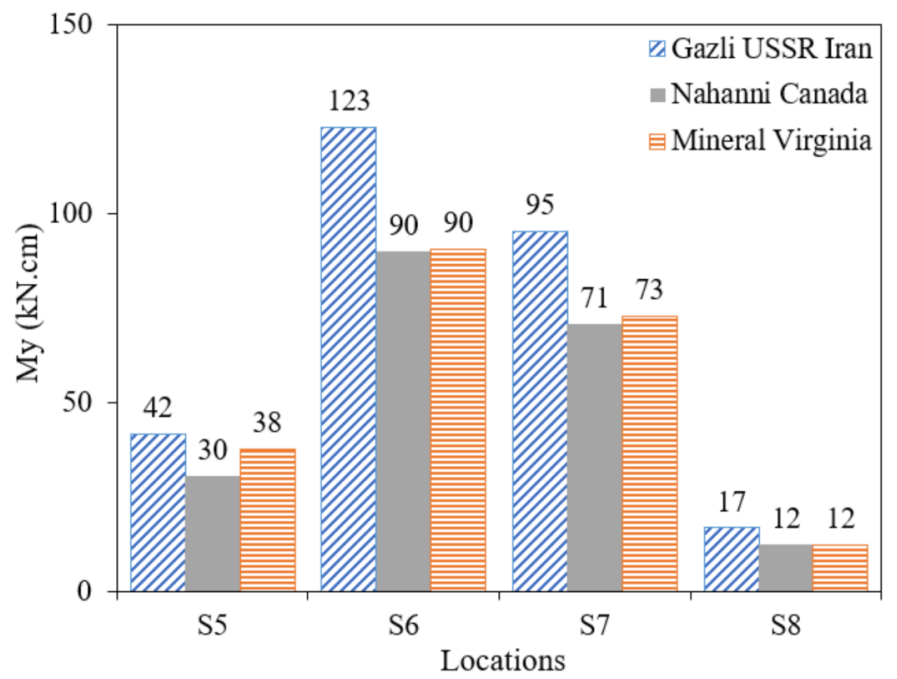

(c)

Figure 7. The maximum internal forces in the seaside leg: (a) Axial force; (b) Moment about the x-axis; (c) Moment about the y-axis.

\subsection{Portal Drift}

The portal drift of the scale container crane was measured at location D1 (landside portal) and D2 (seaside portal) using a camera, as shown in Figure 2. The horizontal displacements at location D1 and D2 relative to the shake table in the trolley boom direction are defined as the portal drift. They are expressed in Equation (3):

$$
\text { Portal drift }=A b_{\text {portal_disp }}-A b_{\text {shake_disp }}
$$

where $A b_{\text {portal_disp }}$ is the absolute displacement at location D1 and D2 obtained from the camera; $A b_{\text {shake_disp }}$ is the absolute displacement at a location on the shake table obtained from the camera. In this study, the absolute displacement of the location D1, D2, and the point on the shake table was determined from a video recorded with the camera using the Kanade-Lucas-Tomasi face detection and tracking algorithm in Matlab software [34-36].

The values of the portal drift of the crane model are shown in Figure 8. Despite the PGA of the near-field ground motion for the shaking table test being lower than that of the far-field ground motions, the portal drift under the near-field Gazli USSR Iran earthquake was higher than that of far-field earthquakes (Nahanni Canada and Mineral Virginia earthquakes). In detail, the seaside portal drift of the near-field Gazli USSR Iran earthquake $(8.1 \mathrm{~mm})$ was $25 \%$ and $43 \%$ higher than that under the far-field earthquakes, Nahanni Canada $(6.1 \mathrm{~mm})$ and Mineral Virginia $(4.6 \mathrm{~mm})$, respectively. The landside portal drift under the Gazli USSR Iran $(8.2 \mathrm{~mm})$ was also $27 \%$ and $44 \%$ higher than that under the Nahanni Canada $(6.0 \mathrm{~mm})$ and Mineral Virginia $(4.6 \mathrm{~mm})$ earthquakes, respectively. Therefore, the near-field ground motion caused larger portal drift than the far-field ground motions. Figure 9 shows the portal drift time history for the three input ground motions. It is observed that there were no differences between seaside and landside portal drift in this study. The positive values indicate movement in the seaside direction relative to its original position, while the negative values indicate movement in the landside direction relative to its original position. 


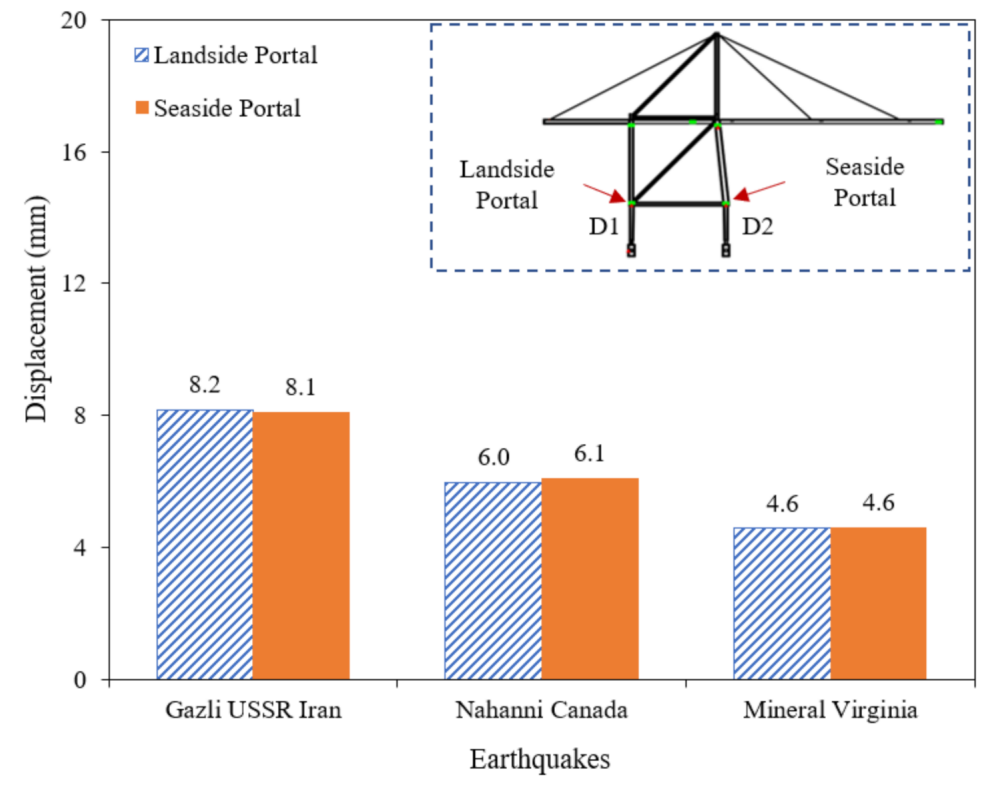

Figure 8. Comparison of portal drift for near-field and far-field earthquakes.

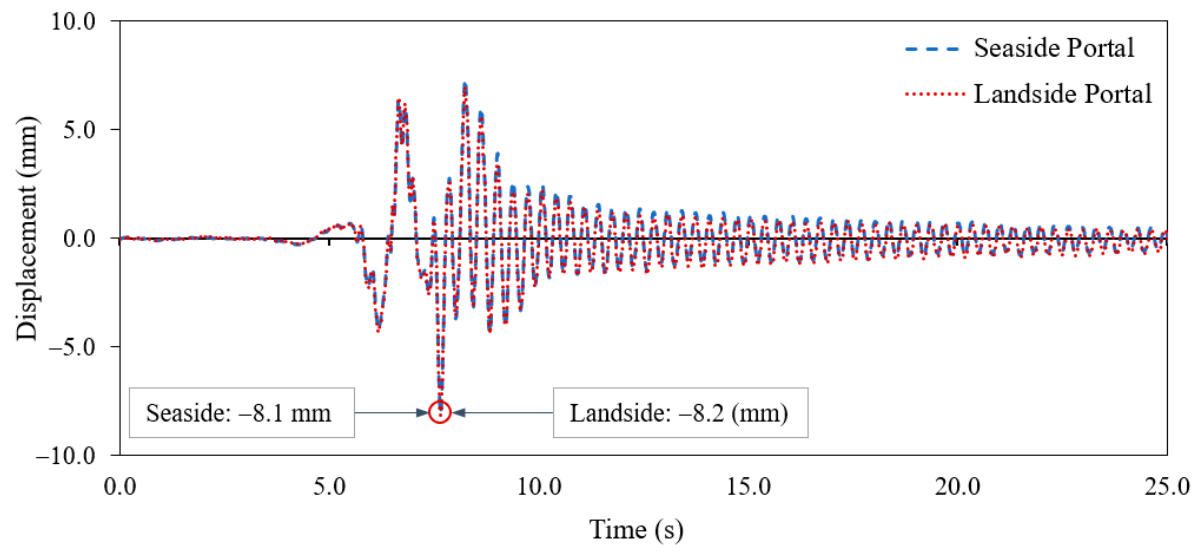

(a)

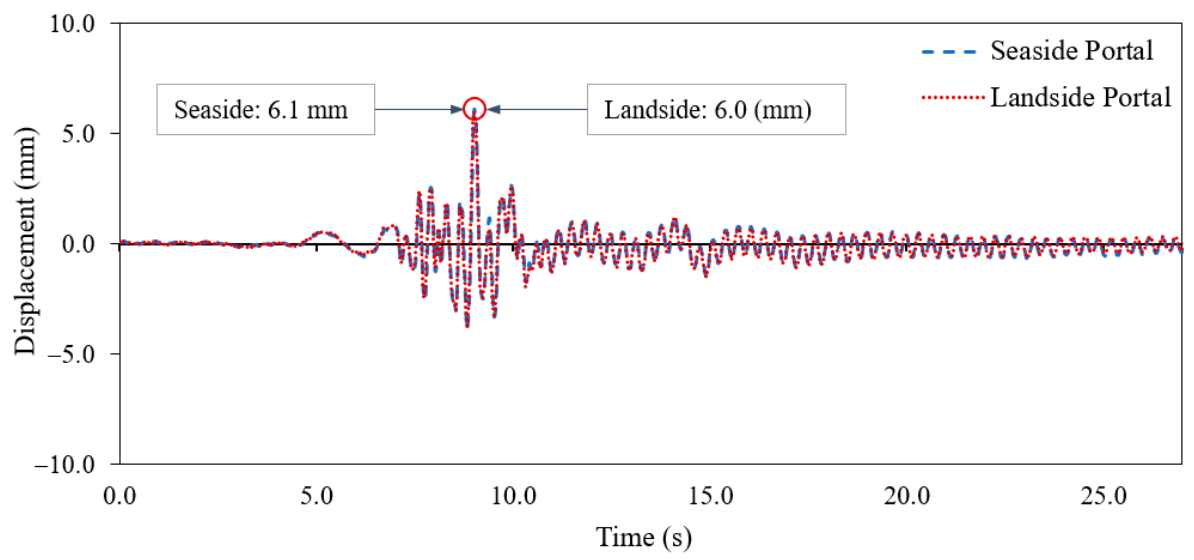

(b)

Figure 9. Cont. 


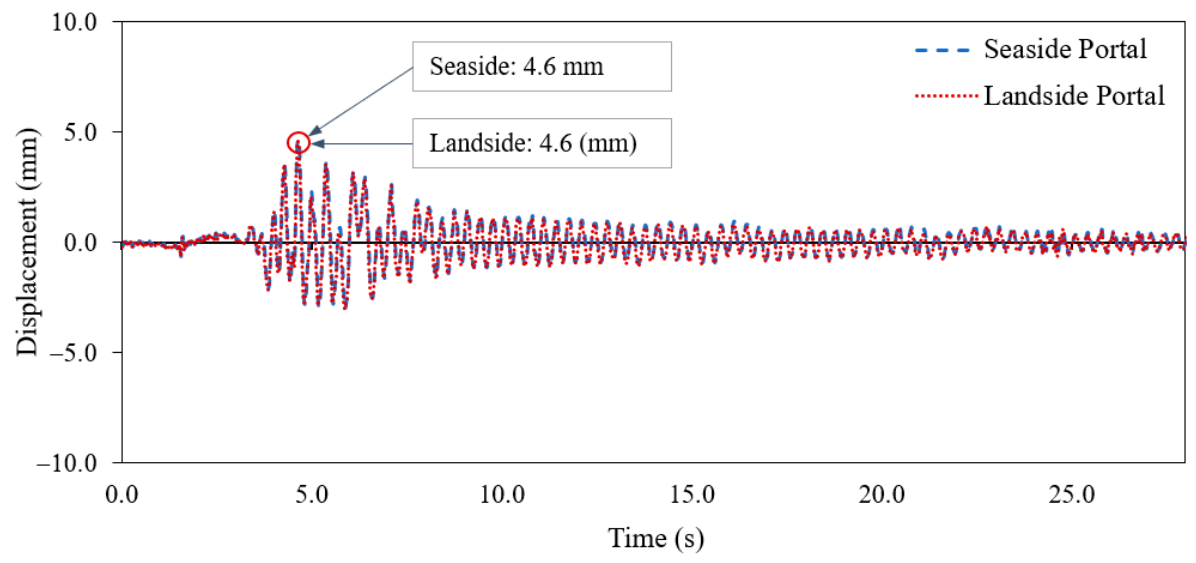

(c)

Figure 9. Time history of portal drift: (a) Gazli USSR Iran earthquake; (b) Nahanni Canada earthquake; (c) Mineral Virginia earthquake.

\subsection{Acceleration Response}

The seismic acceleration response of the scale container crane was recorded at three locations designated as A1, A2, and A3 (see Figure 2). The maximum acceleration response is summarized in Figure 10. The maximum acceleration responses of the scale container crane at locations A1, A2, and A3 are compared with the peak ground acceleration (PGA) of matched input ground motions given in Figure 3b. As shown in Figure 10 clearly, the maximum acceleration responses under the near-field Gazli USSR Iran ground motion increased compared to the input peak acceleration. Specifically, the maximum acceleration response at locations A1 (0.5 g), A2 (0.44 g), and A3 (0.63 g) were $47 \%, 29 \%$, and $85 \%$ higher than the maximum acceleration of input ground motion $(\mathrm{PGA}=0.34 \mathrm{~g})$. However, the maximum acceleration responses under the far-field ground motions decreased compared to the input peak acceleration. In detail, the maximum acceleration of the locations A1 $(0.35 \mathrm{~g})$, A2 $(0.40 \mathrm{~g})$, and A3 $(0.37 \mathrm{~g})$ when subjected to the far-field Mineral Virginia earthquake were $33 \%, 23 \%$, and $29 \%$ lower than its PGA $(0.52 \mathrm{~g})$. For the far-field Nahanni Canada earthquake, there was a marginal or no decrease in the seismic acceleration response of the $\mathrm{A} 3$ and $\mathrm{A} 2$ locations. The maximum acceleration of location $\mathrm{A} 3$ and $\mathrm{A} 2$ was $0.42(\mathrm{~g})$ and $0.44(\mathrm{~g})$, respectively, as compared to the PGA of $0.44(\mathrm{~g})$. The maximum acceleration response of location A1 ( $0.34 \mathrm{~g})$ was $23 \%$ lower than its PGA $(0.44 \mathrm{~g})$. Therefore, it can be concluded that the near-field ground motions have a larger effect on the seismic response of the container crane than the far-field input ground motions.

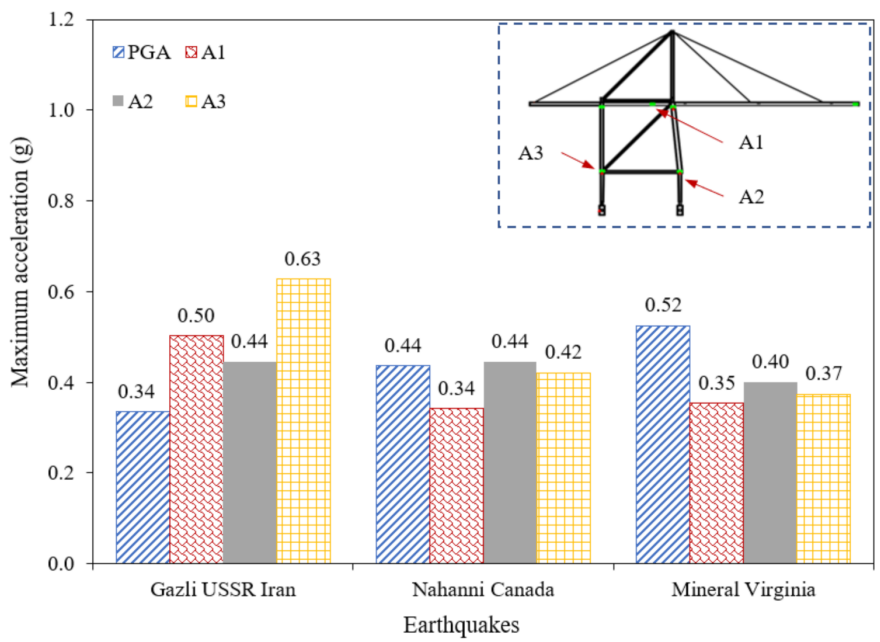

Figure 10. Maximum acceleration response. 


\section{Conclusions}

The container crane's seismic response was evaluated by employing a shaking table test of its $1 / 20$ scale crane. The scale crane was designed based on the similitude law, where the cross-section of each part was scaled down by using the scale factor of the moment of inertia. Besides, added masses were applied to satisfy the scale crane's total mass. One near-field (Gazli USSR Iran) and two far-field (Nahanni Canada and Mineral Virginia) ground motions were matched to the elastic response spectrum (Z1S4_2400) and applied to the scale crane in the trolley-boom girder direction. Major findings obtained from this study are summarized as follows:

Despite having matched the near-field and far-field ground motions to the elastic response spectrum (Z1S4_2400), which was defined as zone 1, soil type S4, and a return period of 2400 years based on the Korean standard, there was still a significant difference in the seismic response of the container crane between the near-field and the far-field ground motions, such as the internal forces in the seaside and landside legs, and portal drift. The internal forces, the axial force and two moments, in the seaside and landside legs when the scale crane was subjected to the near-field motions were higher than when the scale crane was subjected to the far-field motions. For example, at the top of the lower seaside legs, the bending moment $M_{y}$ under the near-field ground motion was $37 \%$ higher than that of the far-field ground motions. The portal drift under the near-field earthquakes was also higher than that of the far-field earthquakes. For example, the seaside portal drifts under the Gazli USSR Iran earthquake were 25\% and 43\% higher than those of the far-field earthquakes, Nahanni Canada and Mineral Virginia.

In the case of near-field input ground motions, which have a wider acceleration and displacement-sensitive region than the far-field ground motions, they will have a more significant effect on the seismic response of the container crane than the far-field ground motions. The maximum acceleration response of the container crane increased as compared to the peak ground acceleration when subjected to the near-field ground motion, but they decreased as compared to the peak ground acceleration when subjected to the far-field ground motions. For example, the maximum acceleration response of the location on the trolley-boom girder when the scale crane was subjected to the Gazli USSR Iran earthquake was $47 \%$ higher than its PGA, while under the Nahanni Canada and Mineral Virginia earthquakes, the maximum acceleration responses were $23 \%$ and $33 \%$ lower than their PGA.

Author Contributions: Conceptualization, V.B.N. and J.H.; methodology, V.B.N. and J.H.; software, V.B.N., B.K.M. and J.K.; validation, J.H. and I.-J.P.; formal analysis, V.B.N. and B.K.M.; investigation, V.B.N. and J.K.; resources, J.H.; data curation, V.B.N.; writing—original draft preparation, V.B.N.; writing—review and editing, J.H. and I.-J.P.; visualization, V.B.N. and B.K.M.; supervision, J.H.; project administration, J.H.; funding acquisition, J.H. All authors have read and agreed to the published version of the manuscript.

Funding: This research was funded by the Ministry of Oceans and Fisheries (20160065), Korea.

Institutional Review Board Statement: Not applicable.

Informed Consent Statement: Not applicable.

Data Availability Statement: The data presented in this study are available on request from the corresponding author.

Acknowledgments: This research is a part of the project titled 'Development of performance-based seismic design technologies for advancement in design codes for port structures,' funded by the Ministry of Oceans and Fisheries (20160065), Korea.

Conflicts of Interest: The authors declare no conflict of interest. 


\section{References}

1. Chang, S.E. Disasters and transport systems: Loss, recovery and competition at the Port of Kobe after the 1995 earthquake. J. Transp. Geogr. 2000, 8, 53-65. [CrossRef]

2. Kobayashi, N.; Kuribara, H.; Honda, T.; Watanabe, M. Nonlinear Seismic Responses of Container Cranes Including the Contact Problem Between Wheels and Rails. J. Press. Vessel Technol. 2004, 126, 59. [CrossRef]

3. Tran, Q.H.; Huh, J.; Nguyen, V.B.; Kang, C.; Ahn, J.-H.; Park, I.-J. Sensitivity Analysis for Ship-to-Shore Container Crane Design. Appl. Sci. 2018, 8, 1667. [CrossRef]

4. Huh, J.; Nguyen, V.B.; Tran, Q.H.; Ahn, J.H.; Kang, C. Effects of Boundary Condition Models on the Seismic Responses of a Container Crane. Appl. Sci. 2019, 9, 241. [CrossRef]

5. Jaradat, O.; Ph, D.; Pe, D.; Asce, M.; Lai, C. Crane-wharf Interaction Nonlinear Time-History Analysis for Pier E Wharf at the Port of Long Beach. In Proceedings of the Port 2013 ASCE, Seattle, WA, USA, 25-28 August 2013; pp. 1255-1264.

6. Tran, Q.H.; Huh, J.; Nguyen, V.B.; Haldar, A.; Kang, C.; Hwang, K.M. Comparative Study of Nonlinear Static and Time History Analyses of Typical Korean STS Container Cranes. Adv. Civ. Eng. 2018, 2018, 2176894. [CrossRef]

7. Tran, Q.H.; Huh, J.; Doan, N.S.; Mac, V.H.; Ahn, J.H. Fragility Assessment of Container Crane under Seismic Excitation Considering Uplift and Derailment Behavior. Appl. Sci. 2019, 9, 4660. [CrossRef]

8. Jin, Y.L.; Wu, T.X.; Li, Z.G. Shaking Table Tests and Numerical Analysis for Vertical Seismic Response of Quayside Container Cranes. Int. J. Struct. Stab. Dyn. 2012, 12, 1250034.

9. Kanayama, T.; Kashiwazaki, A.; Shimizu, N.; Nakamura, I.; Kobayashi, N. Large shaking table test of a container crane by strong ground excitation. Proc. Press. Vessel. Pip. Conf. 1998, 36, 243-249.

10. Jin, Y.; Zhang, X. Experimental seismic analysis of a quayside container crane structure using a scaled model. Proc. Inst. Mech. Eng. Part I J. Syst. Control Eng. 2013, 227, 645-661. [CrossRef]

11. Kosbab, B.D. Seismic Performance Evaluation of Port Container Cranes Allowed to Uplift; Georgia Institute of Technology: Atlanta, GA, USA, 2010.

12. Azeloglu, C.O.; Edincliler, A.; Sagirli, A. Investigation of seismic behavior of container crane structures by shake table tests and mathematical modeling. Shock Vib. 2014, 2014, 682647. [CrossRef]

13. Sugano, T.; Takenobu, M.; Suzuki, T.; Shiozaki, Y. Design procedures of seismic-isolated container crane at port. In Proceedings of the 14th World Conference on Earthquake Engineering, 14th WCEE, Beijing, China, 12-17 October 2008.

14. Kosbab, B.D.; Jacobs, L.D.; Desroches, R.; Leon, R.T. Analysis and testing of container cranes under earthquake loads. Tclee 2009 2009, 357, 80.

15. Moncarz, P.D.; Krawinkler, H. Theory and Application of Experimental Model Analysis in Earthquake Engineering; Stanford University: Stanford, CA, USA, 1981.

16. Harris, H.G.; Sabnis, G.M. Structural Modeling and Experimental Techniques, 2nd ed.; CRC Press: Boca Raton, FL, USA; London, UK; New York, NY, USA; Washington, DC, USA, 1999; ISBN 9780849324697.

17. Jacobs, L.D. Shake Table Experiments for the Determination of the Seismic Response of Jumbo Container Cranes; Georgia Institute of Technology: Atlanta, GA, USA, 2010.

18. Tochaei, E.N.; Taylor, T.; Ansari, F. Effects of near-field ground motions and soil-structure interaction on dynamic response of a cable-stayed bridge. Soil Dyn. Earthq. Eng. 2020, 133, 106115. [CrossRef]

19. Brun, M.; Reynouard, J.M.; Jezequel, L.; Ile, N. Damaging potential of low-magnitude near-field earthquakes on low-rise shear walls. Soil Dyn. Earthq. Eng. 2004, 24, 587-603. [CrossRef]

20. Davoodi, M.; Jafari, M.K.; Hadiani, N. Seismic response of embankment dams under near-fault and far-field ground motion excitation. Eng. Geol. 2013, 158, 66-76.

21. Gorai, S.; Maity, D. Seismic response of concrete gravity dams under near field and far field ground motions. Eng. Struct. 2019, 196, 109292. [CrossRef]

22. Grimaz, S.; Malisan, P. Near field domain effects and their consideration in the international and Italian seismic codes. Boll. Geofis. Teor. Appl. 2014, 55, 717-738.

23. Konstandakopoulou, F.D.; Evangelinos, K.I.; Nikolaou, I.E.; Papagiannopoulos, G.A.; Pnevmatikos, N.G. Seismic analysis of offshore platforms subjected to pulse-type ground motions compatible with European Standards. Soil Dyn. Earthq. Eng. 2020, 129, 105713. [CrossRef]

24. Blachowski, B.; Pnevmatikos, N. Neural network based vibration control of seismically excited civil structures. Period. Polytech. Civ. Eng. 2018, 62, 620-628. [CrossRef]

25. Peng, Q.; Cheng, W.; Jia, H.; Guo, P. Fragility analysis of gantry crane subjected to near-field ground motions. Appl. Sci. 2020, 10, 4219. [CrossRef]

26. Mills, R.S.; Krawinkler, H.; Gere, J.M. Model Tests on Earthquake Simulators-Development and Implementation of Experimental Procedures. Ph.D. Thesis, Stanford University, Stanford, CA, USA, 1979.

27. Yadav, K.K.; Gupta, V.K. Near-fault fling-step ground motions: Characteristics and simulation. Soil Dyn. Earthq. Eng. 2017, 101, 90-104. [CrossRef]

28. Chopra, A.K. Dynamics of Structures-Theory and Application to Earthquake Engineering; William, J.H., Ed.; Prentice Hall: Upper Saddle River, NJ, USA, 2011; ISBN 978-0-13-285803-8. 
29. Malhotra, P.K. Response of buildings to near-field pulse-like ground motions. Earthq. Eng. Struct. Dyn. 1999, $28,1309-1326$. [CrossRef]

30. Korean Design Standard KDS 1710 00. Korea Institute of Civil Engineering and Building Technology; Ministry of Land, Infrastructure and Transport: Seoul, Korea, 2018.

31. Seismosoft. SeismoMatch: Earthquake Software for Response Spectrum. 2018. Available online: http://www.seismosoft.com (accessed on 4 August 2018).

32. Hancock, J.; Watson-Lamprey, J.; Abrahamson, N.A.; Bommer, J.J.; Markatis, A.; McCoy, E.M.M.A.; Mendis, R. An improved method of matching response spectra of recorded earthquake ground motion using wavelets. J. Earthq. Eng. 2006, 10, 67-89. [CrossRef]

33. Alatik, L.; Abrahamson, N. An improved method for nonstationary spectral matching. Earthq. Spectra 2010, 26, 601-617. [CrossRef]

34. Galuk, Y.P.; Nickolaenko, A.; Hayakawa, M. Amplitude variations of ELF radio waves in the Earth-ionosphere cavity with the day-night non-uniformity. J. Atmos. Sol. Terr. Phys. 2018, 169, 23-36. [CrossRef]

35. Guru, D.; Dinesh, R. Non-parametric adaptive region of support useful for corner detection: A novel approach. Pattern Recognit. 2004, 37, 165-168. [CrossRef]

36. Viola, P.A.; Jones, M.J. Rapid Object Detection using a Boosted Cascade of Simple Features. In Proceedings of the 2001 IEEE Computer Society Conference on Computer Vision and Pattern Recognition. CVPR 2001, Kauai, HI, USA, 8-14 December 2001. 